\title{
Effects of Selected Herbs and Vegetables on the Nutritional Quality of Beef Burger and Rat Bioassay
}

\author{
(Kesan Herba dan Sayuran Terpilih ke atas Mutu Pemakanan Burger Daging Lembu dan Bioasai Tikus)
}

\author{
Norhayati Mustafa KHALID, Asma QAmaliah ABdul Hamid, CHANDRASENA RAMAKRishna,

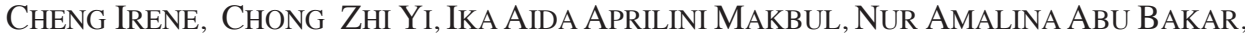 \\ Nurul AZRIANTI ABDUl AZIZ, Nurul HidAYAH A. RAZAK, NuRUl HudA NGADIMEN, \\ SHARIAH LOH LONG \& ABDUL SALAM BABJI*
}

\begin{abstract}
Rat bioassay was used to evaluate the nutritional quality of beef burger as influenced by the addition of selected herbs and vegetables. The selected herbs and vegetables used were pucuk ubi (Mannihot esculenta), pucuk gajus (Anacardium occidentale), pegaga (Centella asiatica) and jantung pisang (Musa paradisiaca) as treatment group with casein and skimmed milk as reference. The rats were fed with herbs and vegetables at the rate of 0.5 (low dose) and 25 (high dose) $\mathrm{g} / \mathrm{kg}$ body weight. The samples were analyzed for proximate analysis, protein quality and protein digestibility. The rats fed with pucuk ubi (high dose) $(364.30 \pm 25.34 \mathrm{~g})$ indicated the highest mean of increased body weight $(121.05 \pm$ $14.65 \mathrm{~g})$ while rats fed with skimmed milk (310.98 $\pm 18.92 \mathrm{~g})$ showed the lowest mean increase in body weight (88.33 $\pm 14.25 \mathrm{~g})$. As for the Protein Efficiency Ratio (PER) value, all the rats fed with herbs diet showed PER values that were significantly lower $(\mathrm{p}<0.05)$ compared to the casein. As for the in vivo apparent protein digestibility test, casein showed the highest digestibility value $(86.33 \pm 4.20)$ while pucuk gajus (high dose) $(59.59 \pm 5.41)$ showed the lowest. As for the in vitro digestibility analyses, casein indicated the highest value for in vitro digestibility (93.84 \pm 0.33$)$. Administration of herbs and vegetables at low and high doses show significant effects $(\mathrm{p}<0.05)$ on nutritional quality of beef burger. In conclusion, it was found that antinutritional factors in selected herbs and vegetables might affect the nutritional quality of beef burger.
\end{abstract}

Keywords: Herbs; nutritional quality; protein digestibility; protein efficiency ratio; vegetables

\section{ABSTRAK}

Bioasai tikus digunakan untuk menilai mutu pemakanan burger daging lembu yang dipengaruhi oleh penambahan herba dan sayuran terpilih. Herba dan sayuran yang terpilih adalah pucuk ubi (Mannihot esculenta), pucuk gajus (Anacardium occidentale), pegaga (Centella asiatica) dan jantung pisang (Musa paradisiaca) yang digunakan sebagai kumpulan rawatan manakala kasein dan susu skim sebagai kumpulan kawalan. Tikus diberi makan herba dan sayuran pada kadar 0.5 (dos rendah) dan 25 (dos tinggi) g/kg berat badan. Sampel dianalisis untuk analisis proksimat, kualiti protein dan penghadaman protein. Tikus yang diberi makan dengan pucuk ubi (dos tinggi) (364.30 $\pm 25.34 \mathrm{~g})$ menunjukkan purata peningkatan berat badan paling tinggi (121.05 $\pm 14.65 \mathrm{~g})$ manakala tikus yang diberi makan dengan susu skim (310.98 \pm $18.92 \mathrm{~g})$ menunjukkan purata peningkatan berat badan yang paling rendah $(88.33 \pm 14.25 \mathrm{~g})$. Bagi nilai nisbah kecekapan protein (PER), semua tikus yang diberi makan dengan diet herba menunjukkan nilai PER yang jauh lebih rendah ( $\mathrm{p}<0.05)$ berbanding dengan kasein. Bagi analisis penghadaman in vivo, kasein menunjukkan nilai penghadaman paling tinggi (86.33 \pm 4.20$)$ manakala pucuk gajus (dos tinggi) (59.59 \pm 5.41$)$ menunjukkan nilai penghadaman paling rendah. Bagi analisis penghadaman in vitro, kasein menunjukkan nilai penghadaman in vitro yang paling tinggi (93.84 \pm 0.33$)$. Pengambilan herba dan sayuran pada dos yang rendah dan tinggi menunjukkan kesan ke atas mutu pemakanan burger daging lembu. Kesimpulannya, kajian ini menunjukkan bahawa faktor-faktor antinutrien dalam herba dan sayuran terpilih mungkin menjejaskan mutu pemakanan burger daging lembu.

Kata kunci: Herba; mutu pemakanan; nisbah kecekapan protein; penghadaman protein; sayuran

\section{INTRODUCTION}

Herbs and vegetables are important sources of dietary fiber, vitamins, minerals and antioxidants (Faridah et al. 2006; Huda-Faujan et al. 2009; Reihani \& Azhar 2012). In Malaysia, herb is commonly eaten fresh as a vegetable (salad and ulam), especially among the Malay communities
(Huda-Faujan et al. 2009). Increased intake of herbs and vegetables are generally associated with a reduced risk of cancer, cardiovascular diseases, hypertension and diabetic (Faridah et al. 2006; Valko et al. 2007). Although herbs and vegetables are a source of fibers, vitamins and minerals, some of these vegetables such as cassava have some 
antinutritional and toxic compounds. These compounds interfere with digestibility and uptake of the nutrients and they might present toxic effects depending on the amount in which they are consumed (Wobeto et al. 2007).

Antinutrients or antinutritional factors may be defined as compounds or substances which act to reduce nutrient intake, digestion, absorption and utilization and may produce other adverse effects (Akande et al. 2010). Pucuk ubi (Mannihot esculenta), pucuk gajus (Anacardium occidentale),pegaga (Centella asiatica) and jantung pisang (Musa paradisiaca) are among herbs and vegetables that contain antinutrient factors. Although it contain antinutrient factors, Malays believe that regular consumption of these herbs and vegetables could cure diabetes, reduced blood pressure and stroke (Rukayah 2000). Cyanide, oxalic acid, saponin and phytic acid are examples of common antinutrient factors found in these herbs and vegetables (Adeolu \& Enesi 2013; Guptaa et al. 2005; Wobeto et al. 2007). In addition, oxalic acid is known to interfere with calcium absorption by forming insoluble salts of calcium (Guptaa et al. 2005). Phytic acid acts as a strong chelator, forming protein and mineral-phytic acid complexes that will reduce protein and mineral bioavailability. In addition, saponins have been shown to bind to the cells of the small intestine thereby affecting the absorption of nutrients across the intestinal wall (Akande et al. 2010).

Rat based Protein Efficiency Ratio (PER) bioassay is an officially approved assay used for protein nutritional quality (AOAC 1980). It has been used extensively to evaluate the quality of protein because it is easy to conduct. PER is the standard used by U.S. food industry to evaluate the quality of protein in foods and to calculate the U.S. Recommended Daily Allowance (USRDA) for protein shown on food tables in the United States (Endres 2001). Furthermore, PER is a measurement of protein quality which is usually used to calculate protein quality by putting young animals on diets at $10 \%$ protein by weight with various test proteins and monitoring their growth. Protein digestibility is also an important parameter in the determination of protein quality. In vivo rat bioassays have been used to determine protein digestibility but they are expensive and time consuming. Furthermore, in vitro method is an alternatives method for determination of protein digestibility that is rapid, convenient and showed strong correlation between in vivo assays (Babji \& Letchumanan 1989).

The objectives of the present study were to evaluate the nutritional quality of beef burger as influenced by the addition of selected herbs and vegetables using in vivo rat bioassay of Protein Efficiency Ratio (PER), as well as invivo digestibility with skimmed milk powder and casein as reference.

\section{MATERIALS AND METHODS}

\section{DRIED HERBS, VEGETABLES AND BEEF PREPARATION}

All herbs, vegetables and frozen beef were obtained from local wet market at Seri Kembangan, Selangor, Malaysia.
The herbs and vegetables were pucuk ubi (Mannihot esculenta), pucuk gajus (Anacardium occidentale), pegaga (Centella asiatica) and jantung pisang (Musa paradisiaca). All herbs and vegetables were washed, finely chopped and oven-dried at $60^{\circ} \mathrm{C}$ in a force-air oven until dry. The dried herbs and vegetables were then ground into powder and stored in airtight containers. The frozen beef at temperature $-18^{\circ} \mathrm{C}$ was manually cut using knife and minced through a $4 \mathrm{~mm}$ diameter grinder plate. The minced meat was then oven-dried at $60^{\circ} \mathrm{C}$ in a force-air oven until dry and ground into powder. At last, the powder was stored in airtight containers for further use.

\section{RAT DIET PREPARATION}

Diet formulation was done using procedures for PER as outlined in AOAC 1984 with casein and skimmed milk powder as the reference protein. Formulated diet was prepared by mixing the dried meat, herbs and vegetables (jantung pisang, pegaga, pucuk ubi and pucuk gajus) powder with other components such as ash mix (USP XVII), vitamin mix AOAC (CA 40055), corn starch, cellulose, sucrose and cooking palm oil (BURUH) and water. The cooking palm oil (BURUH) used contain $100 \%$ high grade pure palm olein. Calculation of ingredient in diet formulation was based on the proximate analyses of the test protein. The formulated diet was then stored at chilled temperature $\left(4^{\circ} \mathrm{C}\right)$ in airtight containers to prevent mould growth. The ratio of dried herb and vegetables calculated for each group was 0.5 (low dose) and 25 (high dose) g/kg of body weight. According to WHO (1993), at least three different dose levels should be used in long term toxicity test. Each type of diet formulation (jantung pisang (low dose), jantung pisang (high dose), pegaga (low dose), pegaga (high dose), pucuk ubi (low dose), pucuk ubi (high dose), pucuk gajus (low dose), pucuk gajus (high dose), skimmed milk and casein) were fed to 6 male and 6 female rats (Sprague-Dawley Strain) obtained from the animal laboratory at Universiti Kebangsaan Malaysia, Bangi, Selangor, Malaysia.

\section{PROXIMATE ANALYSIS}

Proximate analysis of samples was determined according to the standard methods described by Association of Official Analytical Chemists (AOAC 2000). Nitrogen was determined using micro Kjeldahl procedure. Soxhlet method was used to determine the fat content. Oven method was used to determine the moisture and ash content.

\section{RAT BIOASSAY}

Approximately four weeks were taken to conduct the protein quality study for each samples to determine PER and in vivo apparent protein digestibility. The 28 days old rats were randomly distributed into 10 treatment groups and placed in individual cages. The weight of rats used was between 47.8 to $94.2 \mathrm{~g}$ with a mean of $70.3 \pm 10.5 \mathrm{~g}$. Prior to feeding the experimental diets, the rats are placed on an adaptation diet for three days. 


\section{PER ASSAY}

Food and water were supplied ad libitum. Body weight was recorded for 0 day and every three days for 28 days. For determination of feed intake, feces and the spilled feed were collected daily, dried in oven $\left(100^{\circ} \mathrm{C}\right)$ for an hour and analyzed for moisture content before weighing. PER is calculated using the formula:

$$
\text { PER }=\frac{\text { Increase in body weight }(\mathrm{g})}{\text { Weight of protein consumed }(\mathrm{g})} .
$$

\section{IN VIVO APPARENT PROTEIN DIGESTIBILITY (AD)}

Fecal output and food consumption data were recorded daily for eight days (day 10-18) of the 28 days. This is to determine the in vivo protein $\mathrm{AD}$ and was calculated as follow:

$$
\text { In vivo } \mathrm{AD}(\%)=\frac{\mathrm{N} \text { in } \operatorname{diet}(\mathrm{g})-\mathrm{N} \text { in feces }(\mathrm{g}) \times 100}{\mathrm{~N} \text { in } \operatorname{diet}(\mathrm{g})} \text {. }
$$

\section{IN VITRO PROTEIN DIGESTIBILITY}

In vitro protein digestibility of protein food sample was measured using the multi-enzyme described by Satterlee et al. (1979) with casein as the reference. The enzymes used were a mixture of tripsin, chymotrypsin, peptidase and protease. In vitro apparent digestibility was calculated as follow:

In vitro apparent digestibility $=234.84-22.56(\mathrm{X})$.

\section{STATISTICAL ANALYSES}

All statistical computations were performed with ANOVA procedure followed by Duncan of Statistical Packaged for Social Sciences (SPSS) version 21.0. All values are expressed as mean \pm standard deviation (SD).

\section{RESULTS AND DISCUSSION}

\section{PROXIMATE ANALYSES}

Data on proximate analyses of skimmed milk, casein, beef meat, jantung pisang, pegaga, pucuk ubi and pucuk gajus are shown in Table 1. Table 1 indicates that among the herbs and vegetables used in this study, the protein content of pucuk ubi (36.89\%) was the highest, followed by pegaga (19.31\%), pucuk gajus (18.89\%) and jantung pisang $(16.09 \%)$. On the other hand, the protein content for casein is $85.36 \%$. Skimmed milk with protein content of $18 \%$ was used as second control in this study. Skimmed milk is milk with low fat but high in nutritional value and source of high quality animal protein (Camilla et al. 2008). A study from Voon and Kueh (1999) showed that protein contents of indigenous fruit and vegetables of Kuala Lumpur were less than $8 \%$, which is lower than protein content of herbs and vegetables used in this study, including pucuk ubi, pegaga, pucuk gajus and jantung pisang. This indicates that these herbs have higher protein content as compared to the standard protein content for indigenous fruit and vegetables. Besides, a study of Bamishaiye et al. (2011) reported that the protein content in later stage of Moringa oleifera (28.08\%) is lower than the protein content of pucuk ubi (36.89\%). This study obtained that pucuk ubi are better source of protein as compared to Moringa oleifera. Protein is useful for tissue repairing, helps to maintain body's structure and fight against disease infection. In this study, pucuk ubi has the highest protein content among the selected herbs and vegetables studied (pegaga,pucuk gajus and jantung pisang) which indicated pucuk $u b i$ is a better source of protein.

\section{RAT BIOASSAY}

In rat bioassay, all rats survived until the end of the study and gained positive body weight. Based on the data shown in Table 2, the rats fed with pucuk ubi (high) based diet $(121.05 \pm 14.65 \mathrm{~g})$ shown the highest body weight gain, follow by pegaga (high) (120.56 $\pm 23.77 \mathrm{~g})$, pucuk gajus (high) $(116.75 \pm 24.03 \mathrm{~g})$, casein $(115.07 \pm 16.75 \mathrm{~g})$ and pucuk gajus (low) based diet (114.52 $\pm 16.96 \mathrm{~g})$. Rats fed with pucuk ubi (high) based diet shows the highest body weight gain is probably due to pucuk $u b i$ has the highest protein content among the selected herbs and vegetables studied and was shown to have high protein digestibility which contribute to weight gain in rats. However, rats fed with skimmed milk diet were found to have the lowest mean body weight gain $(88.33 \pm 14.25 \mathrm{~g})$. This might be due to skimmed milk based diet preserve the lean body mass of rats whereby it enhanced the partitioning of nutrients towards lean body mass and away from fat mass which lead to low weight gain, weight maintenance or ongoing weight loss in rats (Lindsay \& Reimer 2010). The other four diets which are pucuk ubi (low), pegaga (low) jantung pisang (high) and jantung pisang (low) were

TABLE 1. Proximate analysis of herbs and vegetables, reference casein and skimmed milk (dry basis)

\begin{tabular}{lcccc}
\hline Food & \% Protein & \% Fat & \% Moisture & \% Ash \\
\hline Casein & $83.56 \pm 0.88$ & $0.23 \pm 0.01$ & $8.07 \pm 0.08$ & $0.87 \pm 0.18$ \\
Skimmed milk & $18.00 \pm 0.00$ & $26.00 \pm 0.00$ & $4.22 \pm 1.10$ & $6.42 \pm 0.02$ \\
Jantung Pisang & $16.09 \pm 0.21$ & $7.10 \pm 4.34$ & $8.77 \pm 0.21$ & $19.33 \pm 11.15$ \\
Pegaga & $19.31 \pm 0.09$ & $1.85 \pm 0.52$ & $8.37 \pm 0.21$ & $13.31 \pm 0.05$ \\
Pucuk Ubi & $36.89 \pm 0.55$ & $4.05 \pm 0.19$ & $7.63 \pm 0.31$ & $6.53 \pm 0.02$ \\
Pucuk Gajus & $18.89 \pm 0.35$ & $0.94 \pm 0.06$ & $6.47 \pm 0.21$ & $3.63 \pm 0.03$ \\
\hline
\end{tabular}


found to have no significant difference $(p<0.05)$ on mean body weight gain.

\section{PROTEIN EFFICIENCY RATIO (PER)}

Table 2 shows the PER values for rats fed with 10 respective diets. The results from this study showed PER values of $2.50,1.87,1.72,1.72,1.72,1.66,1.65,1.64,1.54$ and 1.35 for casein, skimmed milk, pegaga (low), pucuk gajus (high), pucuk gajus (low), pegaga (high), pucuk ubi (low), pucuk ubi (high), jantung pisang (low) and jantung pisang (high), respectively. PER for jantung pisang (high) diet was found to be the lowest while casein recorded the highest followed by skimmed milk. PER value for casein diet was significantly higher $(p<0.05)$ compared to the other diet treatments. PER value is important in determining the protein quality in diet. Thus, any value falls above the casein standard value of 2.7 is considered as excellent protein source (Hoffman et al. 2004). In this study, PER value of casein diet is approximately near to the value of casein standard. Hence, it can be concluded that casein protein has higher quality of protein than all other diet treatments. Several studies reported that dietary antinutritional factors affect the protein quality of foods (Gilani et al. 2005; Jansman et al. 1994; Vaintraub \& Bulmaga 1991).

\section{APPARENT PROTEIN DIGESTIBILITY (APD)}

The apparent protein digestibility (APD) of casein, skimmed milk, jantung pisang, pegaga, pucuk ubi and pucuk gajus obtained with the in vivo rat bioassays are shown in Table 3. Casein reference diet treatment showed significantly the highest digestibility of $86.33 \%$ as compared to other diet treatment $(p<0.05)$. Meanwhile, pegaga (low) $(80.76 \%)$ has slightly higher digestibility than jantung pisang (low) $(80.53 \%)$ and pegaga (high) $(80.30 \%)$ but there showed no significant difference $(p>0.05)$. Whereas, pucuk gajus (high) displayed the lowest percentage of digestibility and it is significantly (59.59\%) lower as compared to other diet treatments $(p<0.05)$. From the result, diet containing casein as the source of protein was significantly $(p<0.05)$ more digestible. Mensa-Wilmot et al. (2001) reported that the greater extent of digestibility of casein diet resulted from the higher retention of dietary nitrogen consumed as well as the lower fecal nitrogen output of the rats. In contrast, several studies reported that endogenous losses of amino acids is associated with dietary protein that consist of anti-nutritional factors and decrease the nutritional value of the protein (Caine et al. 1997; Huisman et al. 1993; Rowan et al. 1994; Van Leeuwen et al. 1996). Only true ileum digestibility of amino acids will take these losses into account (Darragh et al. 1998).

The protein digestibility of local herbs obtained with in vitro enzymatic assay is shown in Table 3 . The casein reference had the highest digestibility percentage value (93.61\%) followed by pucuk gajus (low) (80.08\%), pucuk ubi (low) (78.34\%), jantung pisang (low) (77.83\%) and pegaga (low) (77.71\%). The protein digestibility for skimmed milk, pucuk ubi (high), pucuk gajus (high), pegaga (high), and jantung pisang (high) was $71.28 \%$, $74.33 \%, 74.43 \%, 76.58 \%$, and $77.6 \%$, respectively. Jantung pisang (high and low), pegaga (high and low) and pucuk ubi (low) has no significant difference $(p>0.05)$ but are significantly different $(p<0.05)$ from pucuk ubi (high) and pucuk gajus (high). Pucuk gajus (low) is significantly different $(p<0.05)$ from all the other diets.

According to Abbey and Berezi (1988), heat processing especially moist heat has been reported to improve the digestibility of proteins by destroying protease inhibitor and open up the protein structure through denaturation. This might explained the lower digestibility value of all the herbs since no moist heat treatment (boiling) been given to any diet samples except oven drying. These results was supported by Hsu et al. (1977) who found that dry heat processing (roasting) reduced protein digestibility due to non-enzymatic browning.

As comparison, most of the values obtained with in vitro technique were slightly lower as compared with the values determined by in vivo rat assay. This was due to the availability of enzymes present in in vivo technique

TABLE 2. Growth and PER values for rats fed with herbs diets in beef burger

\begin{tabular}{|c|c|c|c|c|c|c|}
\hline Treatment & $\begin{array}{l}\text { Weight gain rats } \\
\text { (g/rat) } \\
\text { (Mean } \pm \text { S.D.) }\end{array}$ & $\begin{array}{l}\text { Total feed intake } \\
\text { (g/rat/28 days) } \\
\mathrm{g} \pm \text { S.D }\end{array}$ & $\begin{array}{c}\text { \% Protein in } \\
\text { feed } \\
(\mathrm{N} \times 6.25)\end{array}$ & $\begin{array}{l}\text { Protein consumed } \\
\text { (g/rat/28 days) } \\
\text { g } \pm \text { S.D. }\end{array}$ & PER & $\begin{array}{c}\text { Adj } \\
\text { PER }\end{array}$ \\
\hline Casein & $115.07 \pm 16.75^{\mathrm{b}}$ & $330.20 \pm 23.47^{b}$ & 10.50 & $34.67 \pm 2.46^{\mathrm{g}}$ & $3.31^{\mathrm{c}}$ & $2.50^{\mathrm{c}}$ \\
\hline Skimmed milk & $88.33 \pm 14.25^{\mathrm{a}}$ & $310.98 \pm 18.92^{\mathrm{a}}$ & 12.06 & $36.01 \pm 4.19^{\mathrm{a}}$ & $2.48^{\mathrm{b}}$ & $1.87^{\mathrm{b}}$ \\
\hline Jantung Pisang (Low) & $110.94 \pm 9.98^{\mathrm{ab}}$ & $362.44 \pm 21.00^{\mathrm{bc}}$ & 15.08 & $54.66 \pm 3.17^{\text {def }}$ & $2.04^{\mathrm{a}}$ & $1.54^{\mathrm{a}}$ \\
\hline Jantung Pisang (High) & $104.14 \pm 26.46^{\mathrm{ab}}$ & $350.05 \pm 40.73^{\mathrm{bc}}$ & 16.42 & $57.48 \pm 6.69^{f}$ & $1.79^{\mathrm{a}}$ & $1.35^{\mathrm{a}}$ \\
\hline Pegaga (Low) & $110.56 \pm 8.61^{\mathrm{ab}}$ & $341.79 \pm 23.55^{\mathrm{bc}}$ & 14.25 & $48.71 \pm 3.36^{\mathrm{bc}}$ & $2.28^{\mathrm{b}}$ & $1.72^{\mathrm{b}}$ \\
\hline Pegaga (High) & $120.56 \pm 23.77^{\mathrm{b}}$ & $373.35 \pm 25.98^{c}$ & 14.67 & $54.77 \pm 3.81^{\mathrm{def}}$ & $2.20^{\mathrm{ab}}$ & $1.66^{\mathrm{ab}}$ \\
\hline Pucuk Ubi (Low) & $100.04 \pm 11.48^{\mathrm{ab}}$ & $340.43 \pm 22.21^{\mathrm{bc}}$ & 13.49 & $45.92 \pm 3.00^{\mathrm{b}}$ & $2.19^{\mathrm{ab}}$ & $1.65^{\mathrm{ab}}$ \\
\hline Pucuk Ubi (High) & $121.05 \pm 14.65^{\mathrm{b}}$ & $364.30 \pm 25.34^{\mathrm{bc}}$ & 15.32 & $55.81 \pm 3.88^{\mathrm{ef}}$ & $2.17^{\mathrm{ab}}$ & $1.64^{\mathrm{ab}}$ \\
\hline Pucuk Gajus (Low) & $114.52 \pm 16.96^{b}$ & $358.08 \pm 26.38^{\mathrm{bc}}$ & 14.01 & $50.17 \pm 3.70^{\mathrm{bcd}}$ & $2.27^{\mathrm{b}}$ & $1.72^{\mathrm{b}}$ \\
\hline Pucuk Gajus (High) & $116.75 \pm 24.03^{b}$ & $375.02 \pm 13.50^{c}$ & 13.71 & $51.42 \pm 1.85^{\mathrm{cde}}$ & $2.28^{\mathrm{b}}$ & $1.72^{\mathrm{b}}$ \\
\hline
\end{tabular}

${ }^{\text {a-f }}$ Different superscripts in the same column are significantly different at $p<0.05$ 
TABLE 3. In vivo and in vitro protein digestibility of different protein source

\begin{tabular}{lcc}
\hline Source of protein & $\begin{array}{c}\text { \% in vitro } \\
\text { digestibility }\end{array}$ & $\begin{array}{c}\text { \% in vivo apparent } \\
\text { digestibility (AD) }\end{array}$ \\
\hline Casein & $93.84 \pm 0.33^{\mathrm{a}}$ & $86.33 \pm 4.20^{\mathrm{a}}$ \\
Skimmed milk & $71.28 \pm 0.33^{\mathrm{b}}$ & $79.95 \pm 4.19^{\mathrm{bc}}$ \\
Jantung Pisang (Low) & $77.83 \pm 0.32^{\text {cdefg }}$ & $80.53 \pm 1.78^{\mathrm{bc}}$ \\
Jantung Pisang (High) & $77.60 \pm 0.32^{\text {cdefg }}$ & $77.96 \pm 3.38^{\mathrm{bc}}$ \\
Pegaga (Low) & $77.71 \pm 0.16^{\mathrm{cdefg}}$ & $80.76 \pm 1.99^{\mathrm{c}}$ \\
Pegaga (High) & $76.58 \pm 0.48^{\text {cdefg }}$ & $80.30 \pm 2.99^{\mathrm{bc}}$ \\
Pucuk Ubi (Low) & $78.34 \pm 0.16^{\text {cdefg }}$ & $73.67 \pm 3.14^{\mathrm{d}}$ \\
Pucuk Ubi (High) & $74.33 \pm 0.16^{\mathrm{hi}}$ & $76.26 \pm 3.35^{\mathrm{bd}}$ \\
Pucuk Gajus (Low) & $80.08 \pm 0.64^{\mathrm{j}}$ & $78.58 \pm 1.76^{\mathrm{bc}}$ \\
Pucuk Gajus (High) & $74.43 \pm 0.32^{\mathrm{hi}}$ & $59.59 \pm 5.41^{\mathrm{e}}$ \\
\hline
\end{tabular}

${ }^{\text {a-i }}$ Different superscripts in the same column are significantly different at $p<0.05$

was different from in vitro technique. The enzymes used in this study were from plant-based enzymes, including trypsin, chymotrypsin, peptidase and protease. Thus, the mechanism of enzymes on protein digestibility in vitro might be different when compared to in vivo apparent digestibility.

The strength of the study is it is one of the first to assess the effects of selected herbs and vegetables on the nutritional quality of beef burger and rat bioassay in Malaysia. It adds knowledge to the effects of selected herbs and vegetables on the nutritional quality of beef burger and rat bioassay.

\section{CONCLUSION}

This study concluded that pegaga (low dose) and pucuk gajus (high dose) had the highest value of PER (1.72) in the rats. However, sample of casein was shown to have the highest value of PER (2.50) among the 10 treatments groups, reflecting highest protein quality. While for in vivo and in vitro digestibility, casein diet displayed the highest value while skimmed milk diet had the lowest percentage of in vitro digestibility and pucuk gajus (high dose) based diet had the lowest percentage of in vivo digestibility. This might be due to the antinutritional factors in selected herbs and vegetables that could affect the nutritional quality of beef burger.

\section{ACKNOWLEDGEMENTS}

The authors would like to thank all the staffs from the Faculty of Science and Technology and Animal Laboratory, Universiti Kebangsaan Malaysia which have been involved throughout the study for all support and assistance.

\section{REFERENCES}

Abbey, B.W. \& Berezi, P.E. 1988. Influence of processing on the digestibility of African yam bean (Sphenostylis stenocarpa) flour. Nutrition Reports International 32: 819-827.

Adeolu, A.T. \& Enesi, D.O. 2013. Assessment of proximate, mineral, vitamin and phytochemical compositions of plantain
(Musa paradisiaca) bract-an agricultural waste. International Research Journal of Plant Science 4(7): 192-197.

Akande, K.E., Doma, U.D., Agu, H.O. \& Adamu, H.M. 2010 Major antinutrients found in plant protein sources: their effect on nutrition. Pakistan Journal of Nutrition 9(8): 827-832.

AOAC. 2000. Official Methods of Analysis. 17th ed. Arlington: Association of Official Analytical Chemist Washington DC. USA.

AOAC. 1980. Official Methods of Analysis. 13th ed. Arlington: Association of Official Analytical Chemists.

Babji, A.S. \& Letchumanan, S. 1989. Measuring protein digestibility using an enzymatic in vitro technique. Proceeding of Nutrition Society of Malaysia Journal 4: 53-58.

Bamishaiye, E.I., Olayemi, F.F., Awagu, E.F. \& Bamshaiye, O.M. 2011. Proximate and phytochemical composition of Moringa oleifera leaves at three stages of maturation. Advance Journal of Food Science and Technology 3(4): 233-237.

Caine, W.R., Sauer, W.C., Tamminga, S., Verstegen, M.W.A. \& Schulze, H. 1997. Apparent ileal digestibilities of amino acids in newly weaned piglets and fed diets with protease-treated soybean meal. Journal of Animal Science 75: 2962-2969.

Camilla, H., Gregers, S.A., Stine, J., Christian, M., Henrik, F., Per, T.S. \& Kim, F.M. 2008. The use of whey or skimmed milk powder in fortified blended foods for vulnerable groups. The Journal of Nutrition 138: 145-161.

Darragh, A.J., Schaafsma, G. \& Moughan, P.J. 1998. Endogenous recoveries of true ileal digestibilities of amino acids in newly weaned piglets fed diets with protease-treated soybean meal. Impact of amino acid availability on the protein digestibility corrected amino acid score. Proceedings of the Nutrition Week of the International Dairy Federation. Wellington: New Zealand.

Endres, J.G. 2001. Soy Protein Products Characteristics, Nutritional Aspects and Utilization. Illinois: AOCS Press.

Faridah, A., Nordin, H.L., Israf, D.A., Khozirah, S. \& Umi Kalsom, Y. 2006. Antioxidant and nitric oxide inhibition activities of selected Malay traditional vegetables. Food Chemistry 95: 566-573.

Gilani, G.S., Cockell, K.A. \& Sepehr, E. 2005. Effects of antinutritional factors on protein digestibility and amino acid availability in foods. Journal of AOAC International 88: 967-987.

Guptaa, S., Lakshmia, A.J., Manjunathb, M.N. \& Prakasha, J. 2005. Analysis of nutrient and antinutrient content of underutilized green leafy vegetables. Food Sciences and Technology 38: 339-345. 
Hoffman, J.R. \& Falvo, M.J. 2004. Protein-which is best? Journal of Sports Science and Medicine 3: 118-130.

Hsu, H.W., Vavak, D.L., Satterlee, L.D. \& Miller, G.A. 1977. A multi-enzyme technique for estimating protein digestibility. Journal of Food Science 42: 1269-1273.

Huda-Faujan, N., Noriham, A., Norrakiah, A.S. \& Babji, A.S. 2009. Antioxidant activity of plants methanolic extracts containing phenolic compounds. African Journal of Biotechnology 8(3): 484-489.

Huisman, J., Verstegen, M.W.A., Van Leeuwen, P. \& Tamminga, S. 1993. Reduction of $N$ Pollution by Decrease of the Excretion of Endogenous $N$ in Pigs. Nitrogen Flow in Pig Production and Environmental Consequences. Wageningen: Pudoc Scientific Publishers.

Jansman, A.F.J., Frohlich, A.A. \& Marquardt, R.R. 1994. Production of proline-rich proteins by the parotid glands of rats is enhanced by feeding diets containing tannins from faba beans (Vicia faba L.). Journal of Nutrition 124: 249-258.

Lindsay, K.E. \& Reimer, R.A. 2010. A high calcium, skim milk powder diet results in a lower fat mass in male, energyrestricted, obese rats more than a low calcium, casein or soy protein diet. Journal of Nutrition 140(7): 1234-1241.

Mensa-Wilmot, Y., Philips, R.D. \& Hangrove, J.C. 2001. Protein quality evaluation of cowpea-based extrusion cooked cereal/ legume weaning mixture. Nutrition Research 21: 849-857.

Reihani, S.F.S. \& Azhar, M.E. 2012. Antioxidant activity and total phenolic content in aqueous extracts of selected traditional Malaysia salad (ulam). International Food Research Journal 19(4): 1439-1444

Rowan,A.M., Moughan, P.J., Wilson, P.J., Maher, K . \& TasmanJones, C. 1994. Comparison of ileal and fecal digestibilities of dietary amino acids in adult humans and evaluation of the pig as a model for animal digestion studies in man. British Journal of Nutrition 71: 29-42.

Rukayah, A. 2000. Ulam dan Sayuran Tempatan Semenanjung Malaysia. Kuala Lumpur: Dewan Bahasa dan Pustaka.

Saterlee, L.D., Marshall, H.F. \& Tennyson, J.M. 1979. Measuring protein quality. Journal of the American Oil Chemists 'Society 56(3): 103.
Valko, M., Dieter, L., Jan, M., Mark, T.D., Cronin, M.M. \& Joshua, T. 2007. Free radicals and antioxidants in normal physiologicalfunctions and human disease. The International Journal of Biochemistry and Cell Biology 39: 44-84.

Van Leeuwen, P., Veldman, A., Boisen, S., Deuring, K., Kempen, G.J.M., Derksen, G.B., Verstegen, M.W.A. \& Schaafsma, G. 1996. Apparent ileal dry matter and crude protein digestibility of rations fed to pigs and determined with the use of chromium oxide $(\mathrm{Cr} 2 \mathrm{O} 3)$ and acid-insoluble ash as digestive markers. British Journal of Nutrition 76: 551-562.

Voon, B.H. \& Kueh, H.S. 1999. The nutritional value of indigenous fruits and vegetables in Sarawak. Asia Pacific Journal of Clinical Nutrition 8(1): 24-31.

Vaintraub, I.A. \& Bulmaga, V.P. 1991. Effect of phytate on the in vitro activity of digestive proteinases. Journal of Agricultural and Food Chemistry 39: 859-861.

Wobeto, C., Correa, A.D., Abreu, C.M.P.D., Santos, C.D.D. \& Pereira, H.V. 2007. Antinutrients in the cassava (Manihot esculenta Crantz) leaf powder at three ages of the plant. Food Science and Technology (Campinas) 27(1): 108-112.

World Health Organization (WHO). 1993. Research Guidelines for the Evaluation of the Safety and Efficacy of Herbal Medicines. Manila: WHO. pp. 35-40.

School of Chemical Sciences and Food Technology Faculty of Science and Technology

Universiti Kebangsaan Malaysia

43600 UKM Bangi, Selangor Darul Ehsan

Malaysia

*Corresponding author; email: daging@ukm.edu.my

Received: 9 March 2016

Accepted: 6 September 2016 